\title{
Arthrospira (Spirulina) Platensis Can Be Considered as a Probiotic Alternative to Reduce Heat Stress in Laying Japanese Quails
}

-Author(s)

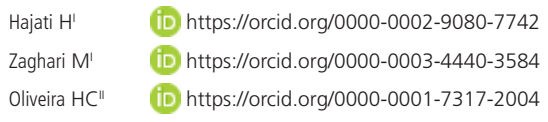

Department of Animal Science, College of Agriculture and Natural Resource, University of Tehran 31587-11167, Karaj, Iran.

Department of Animal Science, Universidade Federal de Viçosa, Viçosa, MG, 36570000, Brazil.

\section{ABSTRACT}

This study was conducted to investigate the effects of Arthrospira platensis (Spirulina platensis, SP) on feed intake, feed conversion ratio, egg weight, hen day egg production, intestinal microflora, heat stress biomarkers, and HSP70 gene expression in laying Japanese quails (Coturnix coturnix japonica) suffering heat stress condition. A total of 250 female quails-were allocated to 5 treatments, 5 replicates and 10 birds in each replicate in a completely randomized design. Experimental treatments included: 1) basal diet, 2) basal diet+ $0.03 \%$ probiotic, 3) basal diet+ $0.1 \% S P, 4)$ basal diet+ $0.3 \% S P, 5)$ basal diet+ $0.5 \%$ $S P$. During the last 6 days of the experiment, the quails were exposed to $8 \mathrm{~h}$ of $34 \pm 1^{\circ} \mathrm{C}$. The birds had free access to feed and water during the experiment. The results showed that using probiotic and different levels of Spirulina had no significant effect on laying performance of Japanese quails ( $p>0.05)$. Probiotic supplement increased Lactobacil bacteria population in laying quails' ileum under heat stress $(p<0.05)$. Different levels of SP decreased Escherichia coli population in laying quails' ileum suffering heat stress $(p<0.05)$.SP at the level of $0.5 \%$ caused the lowest blood Malondialdehyde level, heterophil, and H/L ratio $(p<0.05)$. However, HSP70 gene expression in the heart or the liver of laying quails was not different $(p>0.05)$. In conclusion, the results of the present study revealed that $S P$ at the level of $0.5 \%$ has the potential to be considered as a probiotic alternative in the diet of laying quails suffering heat stress condition.

\section{INTRODUCTION}

Heat stress threats poultry productivity and economic benefits especially on summer days in many countries of the world (Attia et al., 2011; Hajati et al., 2015). Thermo-neutral temperature for adult quails is between $23-26^{\circ} \mathrm{C}$ (Sousa et al., 2013), thus higher environmental temperatures may lead to heat stress in the birds. In fact, stress alter normal behavior, biochemical and physiological processes in birds that disrupts the body homeostasis (Sahin et al., 2009).Oxidative stress induced by heat stress has detrimental effect on egg production by activation of the hypothalamic-pituitary-adrenal (HPA) axis, change the bird's neuroendocrine profile, and reduction of feed intake (Lara \& Rostagno, 2013). Heat stress may lead to intestinal flora disorders in laying birds (Li et al., 2015). It was documented that the expression of heat stress-related genes, like HSP70, increases in heat stress condition (Zhang et al., 2014). In regard to some negative side effects of synthetic antioxidants in the body, poultry nutritionist are searching for organic compounds that can improve the health and welfare of the birds under heat stress condition. In addition, considering the effect of egg quality on human health, organic feeding of laying birds has high concern to ensure the quality of the eggs and support the health state of 
consumers. It was reported that using additives such as probiotics may improve performance, and intestinal microbial ecology of birds suffering heat stress (Sugiharto et al., 2017). Also, it was found that algae contain bioactive compounds, or phytochemicals that may help to consumer's health (Hafting et al., 2012). $S$. platensis is a microalgae-rich in protein, vitamins, minerals, phytopigments (Farag, 2016), gamma linoleic acid, phycocyanins, phenolic acids, betacarotene and chlorophyll (Mariey et al., 2012). These substances have antioxidant (Fazilati et al., 2016), antimicrobial, anti-cancer, and anti-inflammatory activity (Kulshreshtha et al., 2008). Mariey et al. (2012) reported dietary inclusion of $S$. platensis at the levels of $0.1-0.2 \%$ improved egg production in laying hens. Recently, Park et al. (2018) documented that dietary S. platensis improved cecal Lactobacillus population and antioxidant enzyme activity in broiler chickens. However, there is no information about the potential effects of $S P$ in heat-challenged laying quails. Therefore, the aim of the present study was evaluating the effects of Arthrospira platensis on feed intake, feed conversion ratio, egg weight, hen day egg production, intestinal microflora, heat stress biomarkers, and HSP70 gene expression in laying Japanese quails (Coturnix coturnix japonica) suffering heat stress condition.

\section{MATERIALS AND METHODS}

\section{Birds, housing, and rearing conditions}

A total of 250 Japanese laying quails (Coturnix coturnix japonica, 98 days old; $282 \pm 2$ g) with $88.34 \%$ egg production was used in a completely randomized design with 5 treatments, 5 replicates (10 quails in each replicate). The experiment lasted 6 weeks. The quails were placed in wire cages (10 birds/cage) under lighting program of $16 \mathrm{~h} / \mathrm{d}$ light cycle with an average light intensity of $40 \mathrm{lux} / \mathrm{m}^{2}$. During the normal condition (98-134 days of age), the rearing house temperature and relative humidity were kept in $22^{\circ} \mathrm{C}$ and50-60\%, respectively.In order to induce heat stress in the birds, during the last 6 days of the experiment (135-140 days of age), the quails were exposed to 1 h of 22 to $34 \pm 1^{\circ} \mathrm{C}(9: 00$ to $10: 00 \mathrm{AM})$, $8 \mathrm{~h}$ of $34 \pm 1^{\circ} \mathrm{C}$

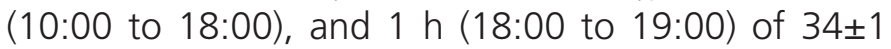
to $22^{\circ} \mathrm{C}$. Also, relative humidity was set from $60 \%$ to $70 \%$. The procedures of this study were approved by the Animal Research Ethical Committee of animal department, University of Tehran.

\section{Diet formulation and additives}

Regarding AOAC's (2007) method, before starting to formulate the experimental diets, feed ingredients were analyzed for crude protein (CP), ether extract (EE), starch and total sugar. Then, metabolisable energy $\left(\mathrm{ME}_{n}\right)$ of the main ingredients was calculated based on analyzed values of the feedstuffs (NRC, 1994). The $\mathrm{ME}_{n}$ of corn was calculated by the following formula: $\mathrm{ME}_{n}=$ $36.21 \times$ crude protein $+85.4 \times$ ether extract +37.26 $x$ nitrogen free extract. The $\mathrm{ME}_{n}$ of soybean meal was calculated by the following formula: $\mathrm{ME}_{n}=37.5 \times$ crude protein $+46.39 \times$ ether extract+ $14.9 \times$ nitrogen free extract. The probiotic used in this experiment containing Bacillus subtilis (21336) $4 \times 10^{9} \mathrm{CFU} / \mathrm{g}$ of the supplement (Biorun company, Iran). The ash, CP, EE, calcium, phosphorus, and total phenol content of $S$. platensis was $12.51 \pm 0.6,64.86 \pm 0.31,4.73 \pm 0.11$, $1.02 \pm 0.08,1.41 \pm 0.09,10.19 \pm 0.04 \mathrm{mg} \mathrm{GAE} / \mathrm{g}$ S. platensis, respectively. Experimental treatments included: 1) basal diet, 2) basal diet+ $0.03 \%$ probiotic, 3) basal diet+ $0.1 \%$ S. platensis, 4) basal diet+ 0.3 $\%$ S. platensis, 5) basal diet+ $0.5 \%$ S. platensis. Basal diet (Table 1) were formulated using WUFFDA software according to nutritional requirements of laying Japanese quails described in NRC (1994).

Table 1 - The ingredients and nutrient compositionof basal diet.

\begin{tabular}{|c|c|}
\hline Ingredients $\left(\mathrm{g} \mathrm{kg}^{-1}\right)$ & 98-140 days* \\
\hline Yellow Corn & 530.0 \\
\hline Soybean meal (44\%) & 356.3 \\
\hline Vegetable oil & 35.0 \\
\hline Oyster shell & 58.0 \\
\hline Mono calcium phosphate & 11.0 \\
\hline Common salt $(\mathrm{NaCl})$ & 3.5 \\
\hline DL-Methionine & 1.2 \\
\hline Vitamin and mineral premix ${ }^{1}$ & 5.0 \\
\hline \multicolumn{2}{|l|}{ Calculated contents } \\
\hline $\mathrm{ME}\left(\mathrm{MJ} \mathrm{kg}{ }^{-1}\right)$ & 12.12 \\
\hline Crude protein $\left(\mathrm{g} \mathrm{kg}^{-1}\right)$ & 199.7 \\
\hline Calcium $\left(\mathrm{g} \mathrm{kg}^{-1}\right)$ & 25.0 \\
\hline Available phosphorus $\left(\mathrm{g} \mathrm{kg}^{-1}\right)$ & 3.60 \\
\hline Sodium $\left(\mathrm{g} \mathrm{kg}^{-1}\right)$ & 1.5 \\
\hline Methionine $\left(\mathrm{g} \mathrm{kg}^{-1}\right)$ & 4.4 \\
\hline Lysine $\left(\mathrm{g} \mathrm{kg}^{-1}\right)$ & 11.0 \\
\hline Methionine + Cystine $\left(\mathrm{g} \mathrm{kg}^{-1}\right)$ & 7.7 \\
\hline Threonine $\left(\mathrm{g} \mathrm{kg}^{-1}\right)$ & 7.7 \\
\hline \multicolumn{2}{|l|}{ Analyses contents $\left(\mathrm{g} \mathrm{kg}^{-1}\right)$} \\
\hline Dry matter (DM) & 896.3 \\
\hline Crude protein & 198.9 \\
\hline Crud fat & 51.4 \\
\hline Crude fiber & 33.4 \\
\hline
\end{tabular}

'vitamin and mineral premix supplied the followings per kilogram of diet: A: 10000 IU; vitamin D: 3000 IU; vitamin E: 20 IU; vitamin K: 2 mg; Thiamin: 2 mg; Pyridoxine hydrochloride: $4 \mathrm{mg}$; Cobalamin: 0.06 mg; Calcium-D-pantothenate: 20 mg; Nicotinic acid: 50 mg; Folic acid: 1 mg; Riboflavin: 8 mg; Biotin: 0.2 mg; Cu: 10 mg; Fe: 60 mg; Zn: $60 \mathrm{mg}$ : Mn: $80 \mathrm{mg}$; Se: $0.2 \mathrm{mg}$ and I: $0.3 \mathrm{mg}$. "Control group was fed the basal diet. The other groups fed the same basal diet supplemented with probiotic $(0.3 \mathrm{~g} / \mathrm{kg})$, or SP powder at the levels of 1,3, or $5 \mathrm{~g} \mathrm{SP/} \mathrm{kg}$ diet. 
During the experiment, a batch of basal diet was made weekly, and then divided into five equal portions, the definite dosage of probiotic and $S$. platensis added on top of each diet and mixed to make the five dietary treatments.

\section{Measurements}

\section{Feed intake, feed conversion ratio, Egg weight and hen day egg production}

Average feed intake per bird was measured weekly by subtracting the left-over feed from the quantity originally supplied to the quails in each pen. Feed conversion ratio (FCR) was calculated by dividing the daily feed intake (FI) to egg mass (average egg number $x$ average egg weight) in each pen and adjusted for mortality. Every day, the eggs from each replicate were weighed, and then the average egg weight was calculated weekly. Hen day egg production was calculated by the following formula: egg production = number of egg production on each day/number of hens alive on that day $\times 100$ (North \& Bell, 1990).

\section{Ileal microflora population}

At 134(before heat stress) and140(under heat stress) days of age, considering the average weight of the birds in each pen, two quails from each pen were selected and slaughtered by cervical dislocation. The ileum content (from Meckel's diverticulum to ileocecal junction) were quickly collected into sterile plastic containers under $\mathrm{CO}_{2}$ and frozen at $-80^{\circ} \mathrm{C}$ to determine E. coli and Lactobacillus counts according to Hu et al. (2012). Two $\mathrm{ml}$ sterilized saline were used to dilute 0.2 $\mathrm{g}$ of ileal content, then 10 -fold serial dilutions $\left(10^{-4}, 10\right.$ ${ }^{-5}$ and $10^{-6}$ ) were prepared. A $100 \mu \mathrm{l}$ of the dilutions was transferred onto sterile plates. Lactobacillus count were assessed on DeMan, Rogosa and Sharpe (MRS) agar at $37^{\circ} \mathrm{C}$ after $48 \mathrm{~h}$, and Escherichia coliO157:H7(E. coli) colonies were measured on MacConkey agar at $37^{\circ} \mathrm{C}$ after $24 \mathrm{~h}$. The bacterial count expressed as $1 \mathrm{~g}$ colony forming units (CFU) per gram of ileal content.

\section{Malondialdehyde concentration, Glutathione Peroxidase activity, heterophil, lymphocyte, H/L ratio, HSP70 gene expression}

At 134 (before heat stress) and 140 (under heat stress) days of age, two quails considering the weight near to the average weight of each pen were selected to collect $2 \mathrm{ml}$ of blood sample from the jugular vein using a syringe 20 -gauge needle. Then, blood samples were centrifuged at 3,000 $\times \mathrm{g}$ for $10 \mathrm{~min}$, and sera were collected. Malondialdehyde (MDA) content was measured using thiobarbituric acid (TBA) and spectrophotometer ( $n=50$, Mihara and Uchiyama 1978). Absorbance of samples was recorded at 532 $\mathrm{nm}$ wavelength using a spectrophotometer.

Also, blood hemolysate of two quails from each pen was prepared on the $134^{\text {th }}$ and $140^{\text {th }}$ days of age. A commercially Glutathione Peroxidase (GPx) kit (Randox, Crumlin, UK) was used to determine GPx activity according to the methodology of Paglia and Valentine (1967). The absorbance of the samples was recorded at $340 \mathrm{~nm}$ wavelength using a spectrophotometer $(n=50)$.

To measure the percentages of heterophil, lymphocyte, and $\mathrm{H} / \mathrm{L}$ ratio, blood smears of two birds from each cage were air-dried on the $134^{\text {th }}$ and $140^{\text {th }}$ days of age. Then, stained with Wright-Giemsa stain (Saikin Kagaku Institute Co. Ltd., Sendai, Japan), and counted to a total of 100 cells per slide, using a Zeiss (Jena, Germany) compound light microscope at a magnification of $100 \times$ with oil immersion $(n=50)$.

For evaluating HSP70 gene expression, at the end of the experiment (140 d) heart and liver samples of birds were washed with normal saline, put into the liquid nitrogen tank and transferred to a- $80^{\circ} \mathrm{C}$ freezer. Total RNA was extracted from homogenized heart and liver (100 mg, n=25) by TRIZOL reagent kit (Invitrogen Inc., (A, USA) according to the manufacturer's instruction. Assessing the quality and quantity of the extracted RNA by ND-1000 UV-Vis spectrophotometer, RNA integrity was assessed by gel-electrophoresis, melting curve and amplification plot of HSP70 gene was done (Figure 1a, b, c, d). Synthesis of the primers was done by SinaClon company. The primers for HSP70 (NM_001323199.1) and Beta-actin (AF199488) were as follows, respectively:

Forward 5' CCGCATCACTCCATCCTACG3',

Reverse 5' CCGCTTGGCATCAAACACAG 3',

Forward 5' CTGGCACCTAGCACAATGAA 3',

Reverse 5' CTGCTTGCTGATCCACATCT 3',

PCR program include 40 cycles of $95^{\circ} \mathrm{C}$ for $15 \mathrm{~s}$, $62^{\circ} \mathrm{C}$ for $30 \mathrm{~s}, 72^{\circ} \mathrm{C}$ for $30 \mathrm{~s}$. Standard melt curve was implemented. All reactions were in triplicate to find the average $\mathrm{Ct}$ value. The $\beta$-actin gene has been used as reference gene. For data analysis and relative expression calculation the $\Delta \Delta C T$ methodology and $2^{\wedge}-\Delta \Delta C T$ (Livak, 2001; Hajati et al., 2015) assessed to find the fold change of treatments against control samples. Briefly, we calculated $\Delta \mathrm{Ct}$ by subtracting the $\mathrm{Ct}$ amount of HSP70 gene from $\mathrm{Ct}$ of $\beta$-actin for each sample, then $\Delta \Delta \mathrm{Ct}$ was calculated by subtracting $\Delta \mathrm{Ct}$ of each group from $\Delta \mathrm{Ct}$ of control group. 

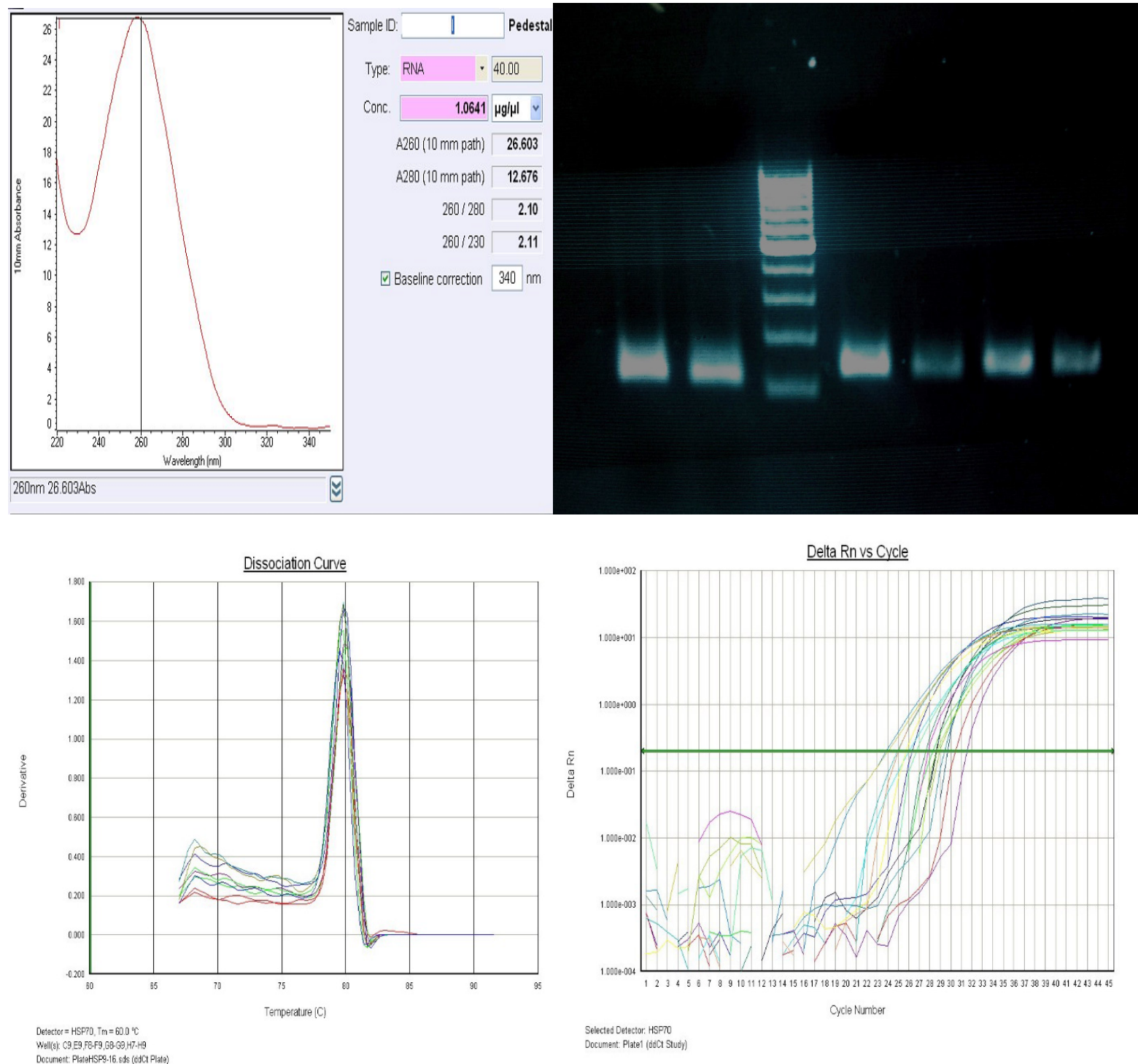

Figure 1-a - assessing the quality and quantity of the extracted RNA by ND-1000 UV-Vis spectrophotometer; b: PCR products of Beta-actin with 123 bp (1, 2, 3 columns) and HSP70 with 115 bp (4, 5, 6 columns); c: melting curve of HSP70 gene products; d: amplification plot of HSP70 gene.

\section{STATISTICAL ANALYSIS}

All the data were analyzed by SAS 9.1.3, ANOVA procedure (SAS 2006). Mean comparison was done by Duncan test, and the results were considered statistically significant when $p<.05$. Statistical model of this experiment was as follow: $\mathbf{X i j}=\mu+\mathrm{Ti}+$ eij, where, $\mu$ was overall mean, Ti was the effect of treatment, eij was experimental error.

\section{RESULTS AND DISSCUSSION}

Feed intake, feed conversion ratio, egg weight, and hen day egg production

Table 2 shows that the supplementation of different levels of dietary SP and probiotic had no significant effect on feed intake ( $\mathrm{g} / \mathrm{bird} /$ day), $F C R$, egg weight ( $\mathrm{g}$ ) and hen day egg production (\%) of laying Japanese quails $(p>0.05)$. In agreement with these results, Rezaeipour et al. (2015) found that s the supplementation of multi strains probiotic (Primalac) had no significant effect on feed intake and FCR of Japanese quails. Also, Hajiaghapour \& Rezaeipour (2018) reported that probiotic supplementation did not alter feed intake, egg weight and egg mass in quail breeders. Dogan et al. (2016) reported that there was no significant difference on feed intake, FCR, egg production, and egg weight in quails fed with different levels of SP. Abouelezz (2017) used SP in the feed $(1 \%)$ and drinking water $(0.25 \%)$ of the laying Japanese quails. The researcher reported there was no significant difference on egg production of the birds. 
Table 2 - Effects of probiotic and Arthrospiraplatensis (Spirulina platensis)on feed intake (g/bird/day), feed conversion ratio $(\mathrm{g} / \mathrm{g})$, egg weight $(\mathrm{g})$, and hen day egg production (\%) of laying Japanese quails from 98-140 $\mathrm{d}$ of age.

\begin{tabular}{|c|c|c|c|c|c|c|c|}
\hline \multirow[b]{2}{*}{$p$ value } & \multicolumn{4}{|c|}{$\mathrm{SP}^{1}(\%)$} & \multirow[b]{2}{*}{ probiotic } & \multirow[b]{2}{*}{ Control } & \\
\hline & $\mathrm{SEM}^{2}$ & 0.5 & 0.3 & 0.1 & & & \\
\hline 0.516 & 1.714 & 33.89 & 33.81 & 33.68 & 33.05 & 33.21 & Feed intake (g/bird/day) \\
\hline 0.068 & 0.073 & 3.20 & 3.15 & 3.14 & 3.09 & 3.11 & Feed conversion ratio $(\mathrm{g} / \mathrm{g})$ \\
\hline 0.607 & 0.398 & 12.44 & 12.48 & 12.39 & 12.51 & 12.32 & Egg weight (g) \\
\hline 0.988 & 2.938 & 85.05 & 85.84 & 86.57 & 85.41 & 86.49 & Hen day egg production (\%) \\
\hline
\end{tabular}

SpirulinaPlatensis, ${ }^{2}$ Standard error of mean.

However, Mariey et al. (2012) reported that using dietary S. platensis $(0,0.10,0.15$ or $0.20 \%)$ improved egg production, egg weight and daily egg mass in local layer hens in Egypt. This is not in agreement with our findings. The differences may be due to the different types of birds and climate conditions.

\section{Ileal microflora population}

As shown in Table 3, before heat stress condition (134 d), supplementation of different levels SP or probiotic decreased $E$. coli count in ileum content of the laying quails $(p<0.05)$. Adding $0.5 \%$ SP caused the lowest ileal E. coli count of the quails. However, there was no difference in Lactobacillus count of the birds on d 134 ( $p>0.05)$. Also, different levels of SP or probiotic decreased $E$. Coli count in ileum content of the laying quails suffering heat stress condition on $140 \mathrm{~d}(p<0.05)$. Probiotic supplement increased Lactobacillus count in ileal content of the birds under heat stress on $140(p<0.05)$.

Table 3 - Effects ofprobiotic and Arthrospiraplatensis (Spirulina platensis)on ileal Lactobacillus and Escherichia coli in laying Japanese quails before (134 d) and under heat stress (140 d) condition.

\begin{tabular}{|c|c|c|c|c|c|c|c|}
\hline \multirow[b]{2}{*}{$p$ value } & \multirow[b]{2}{*}{ SEM $^{1}$} & \multicolumn{3}{|c|}{ SP (\%) } & \multirow[b]{2}{*}{ probiotic } & \multirow[b]{2}{*}{ Control } & \\
\hline & & 0.5 & 0.3 & 0.1 & & & \\
\hline & & & & & & & $134 \mathrm{~d}$ (before heat stress) \\
\hline 0.0001 & 0.263 & $0.2^{c}$ & $0.6^{c}$ & $0.8^{c}$ & $2.0^{\mathrm{b}}$ & $3.0^{\mathrm{a}}$ & Escherichia coli (log 10 CFU g $\left.^{-1}\right)$ \\
\hline \multirow{2}{*}{0.539} & 0.487 & 1.68 & 1.9 & 1.42 & 2.42 & 1.96 & Lactobacillus (log 10 CFU g ${ }^{-1}$ ) \\
\hline & & & & & & & $140 \mathrm{~d}$ (under heat stress) \\
\hline 0.0001 & 0.349 & $2.6^{c}$ & $4.4^{\mathrm{b}}$ & $5.6^{b}$ & $3.6^{b c}$ & $7.6^{\mathrm{a}}$ & Escherichia coli (log 10 CFU g $\left.{ }^{-1}\right)$ \\
\hline 0.028 & 0.288 & $2.36^{\mathrm{b}}$ & $2.8^{\mathrm{b}}$ & $2.74^{\mathrm{b}}$ & $4.8^{\mathrm{a}}$ & $3.0^{\mathrm{b}}$ & Lactobacillus (log 10 CFU q $^{-1}$ ) \\
\hline
\end{tabular}

Means within the same row with uncommon superscript differ significantly $(p<0.05)$. ${ }^{1}$ Standard error of mean.

Researchers found that feeding diets containing Bacillus subtilis decreased cecal $E$. coli count in Japanese quails (Manafi et al., 2016). Qureshi et al. (1996) reported that SP had antimicrobial activity that improved chicken defence system. It was documented that the extract of SP was able to inhibit the growth of Klebsiellapneumoniae, Shigellashigae, E. coli, S. aureus, Proteus vulgaris, Pseudomonas aeruginosa and Salmonella typhi (Mala et al., 2009).The antibacterial activity of the algae extract could be due to the presence of different chemicals such as 1-Octadecene, 1-Heptadeceane (Mishra \& Sree 2007), flavonoids, triterpenoids, phenolic compounds, fatty acids (Demule et al., 1996, Lampe et al., 1998), acrylic acid (Pradhan et al., 2014) free hydroxyl group (Yu et al., 2009). In agreement with our result, Shanmugapriya et al. (2015) found that using dietary SP decreased $E$. coli count in the ileal and caecal digesta of broiler chickens, however, dietary SP increased Lactic acid bacteria count in the intestine. It is interesting to note that gastrointestinal disorderswhich causediarrhea may increase in birds faced with stressors, and performance of these birds may decrease significantly (Manafi, 2015). It was reported that antibiotic alternatives such as prebiotic and probiotic are more effective under heat stress condition (Sohail et al., 2012).

\section{MDA concentration, GPx activity, heterophil, lymphocyte, H/L ratio, HSP70 gene expression}

The results showed that adding different levels of dietary SP and probiotic had no significant effect on blood MDA concentration, GPx activity, heterophil (\%), Lymphocyte (\%), and $\mathrm{H} / \mathrm{L}$ ratio in laying Japanese quails before heat stress condition (134 $d, p>0.05$ ). On d 140, different levels of dietary SP and probiotic decreased MDA concentration $(p<0.05)$, percentage of heterophil $(p<0.05)$, and $H / L$ ratio $(p<0.05)$ in quails suffering from heat stress condition (Table 4). Supplementation of S. platensis increased the 
Table 4 - Effects of probiotic andArthrospiraplatensis (Spirulina platensis) on blood malondialdehyde (MDA) concentration $(\mu \mathrm{mol} / \mathrm{l})$, glutathione peroxidase activity $(\mathrm{U} / \mathrm{L})$, heterophil (\%), Lymphocyte (\%), and H/L ratio in laying Japanese quails before (134 d) and under heat stress (140 d) condition.

\begin{tabular}{|c|c|c|c|c|c|c|c|}
\hline \multirow[b]{2}{*}{$p$ value } & \multirow[b]{2}{*}{$\mathrm{SEM}^{2}$} & \multicolumn{3}{|c|}{$\mathrm{SP}^{1}(\%)$} & \multirow[b]{2}{*}{ probiotic } & \multirow[b]{2}{*}{ Control } & \\
\hline & & 0.5 & 0.3 & 0.1 & & & \\
\hline & & & & & \multicolumn{3}{|c|}{$134 \mathrm{~d}$ (before heat tress) } \\
\hline 0.278 & 0.361 & 2.00 & 2.08 & 2.15 & 2.12 & 2.23 & $\mathrm{MDA}(\mu \mathrm{mol} / \mathrm{l})$ \\
\hline 0.723 & 34.21 & 404.2 & 413.3 & 424.1 & 419.6 & 442.3 & GPx (U/L) \\
\hline 0.188 & 1.583 & 28.1 & 28.7 & 29.3 & 29.5 & 31.3 & Heterophil (\%) \\
\hline 0.474 & 1.917 & 62.3 & 62.4 & 61.7 & 61.2 & 59.4 & Lymphocyte (\%) \\
\hline \multirow[t]{2}{*}{0.119} & 0.071 & 0.45 & 0.45 & 0.47 & 0.48 & 0.52 & $\mathrm{H} / \mathrm{L}$ ratio \\
\hline & & & & & \multicolumn{3}{|c|}{$140 \mathrm{~d}$ (under heat stress) } \\
\hline 0.038 & 0.058 & $2.07^{c}$ & $2.54^{\mathrm{bc}}$ & $2.73^{\mathrm{bc}}$ & $3.52^{b}$ & $6.09^{a}$ & $\mathrm{MDA}(\mu \mathrm{mol} / \mathrm{l})$ \\
\hline 0.804 & 42.11 & 502.5 & 511.3 & 521.6 & 523.2 & 532.7 & GPx (U/L) \\
\hline 0.031 & 1.681 & $25.80^{c}$ & $27.08^{b c}$ & $27.60^{b c}$ & $29.44^{b}$ & $32.32^{\mathrm{a}}$ & Heterophil (\%) \\
\hline 0.034 & 1.603 & $63.40^{a}$ & $62.20^{\mathrm{ab}}$ & $61.48^{\mathrm{ab}}$ & $60.20^{b c}$ & $58.20^{c}$ & Lymphocyte (\%) \\
\hline 0.0001 & 0.012 & $0.40^{c}$ & $0.43^{b c}$ & $0.44^{\mathrm{bc}}$ & $0.48^{b}$ & $0.55^{a}$ & $\mathrm{H} / \mathrm{L}$ ratio \\
\hline
\end{tabular}

Means within the same row with uncommon superscript differ significantly $(p<0.05) .{ }^{1}$ SpirulinaPlatensis, ${ }^{2}$ Standard error of mean.

percentage of lymphocyte in laying quails on d 140 $(p<0.05)$. Adding $S$. platensis and probiotic did not have significant effect on HSP70 gene expression in heart (Figure 2 ) or liver (Figure 3 ) of laying quails under heat stress condition $(p<0.05)$. However, HSP70 gene expression decreased numerically in the heart and liver of the birds and the lowest amount HSP70 gene expression was related to the groups fed with dietary S. platensis at the levels of 0.3 or $0.5 \%$.

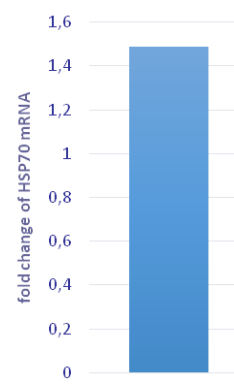

Control

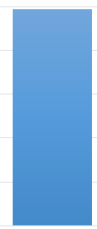

SP1

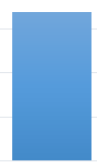

SP2

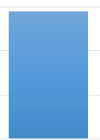

SP3 value $=0.5829$

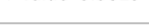

Figure 2 - Relative mean fold change of HSP70 mRNA in heart of laying Japanese quails under heat stress condition. SP1: SP powder at the level $0.1 \%$, SP2: SP powder at the level of $0.3 \%$, SP3: SP powder at the level of $0.5 \%$. $(n=25)$

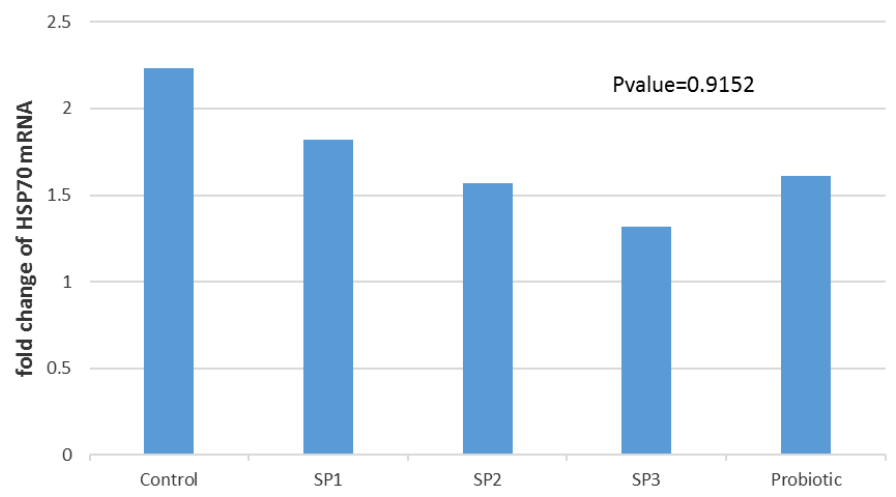

Figure 3 - Relative mean fold change of HSP70 mRNA in liver of laying Japanese quails under heat stress condition. SP1: SP powder at the level 0.1\%, SP2: SP powder at the level of $0.3 \%$, SP3: SP powder at the level of $0.5 \%$. $(n=25)$
One of the final products of polyunsaturated fatty acids peroxidation in the cells is MDA, which consider a marker of oxidative stress. Mahmoud et al. (2004) found a strong relationship between lipid oxidation and HSP70 synthesis in stressed cells. Georgieva et al. (2006) documented that increased levels of MDA and decreased activities of serum antioxidant enzymes such as GPx show imbalance in body oxidants/ antioxidants system, and the birds suffer oxidative stress. Antioxidant nutrients and enzyme defenses are fundamental protectors under stressful condition (Ojha et al., 2010). In present study, SP supplementation at the level of $0.5 \%$ yielded the lowest MDA, heterophil $\%$, and $\mathrm{H} / \mathrm{L}$ ratio (as an acceptable index of stress) in laying quails. In agreement with this result, Mirzaie et al. (2018) reported that using dietary SP under high ambient temperature reduced $\mathrm{H} / \mathrm{L}$ ratio in broiler chickens under heat stress. The antioxidant effect of $S P$ in the quail's body may be related to the presence of wide range of antioxidant compounds in SP. They include B-carotene, astaxanthin, phycocyanin, phycoerythrin, and sulfated polysaccharides such as fucoidans and heterofucans (Chu, 2011; Klein \& Buchholz, 2013). It is interesting to notice that phycocyanin is almost 16 times more effective than trolox (vitamin E analog) and 20 times more efficient than vitamin C as an antioxidant (Romay et al., 2000). Researchers reported that using dietary astaxanthin decreased the amount of thio-barbituric acid-reactive substances (TBARS) in egg yolks (Yang et al., 2006). Also, salicylic, trans-cinnamic, synaptic, chlorogenic, quinic, and caffeic acids are phenolic substances of $S P$ that have antioxidant properties (Miranda et al., 1998). It is well documented that heat stress in quails may 
increase lipid peroxidation and HSP expression (Sahin et al., 2009). Among heat shock proteins, HSP70 shows the highest up-regulation under stressful situations. This may be due to the higher amount or activity of the heat shock transcription factor (Craig \& Gross, 1991).

In a previous study, it was found that polyphenol content of organic additives lowered HSP70 gene expression in broiler chickens suffering from heat stress condition (Hajati et al., 2015). The observedHSP70 gene expression numerically reduction might be related to the presence of $\beta$-carotene, vitamin $C$, vitamin $E$, selenium, manganese, or phenolic compound (10.19 \pm $0.04 \mathrm{mg} \mathrm{GAE} / \mathrm{g}$ ) in S. platensis with radical scavenging, hydrogen or electron donating, metal chelating activity (Balasundrum et al., 2006), cell signaling pathways and gene expression effects (Rodrigo et al., 2011).

\section{CONCLUSIONS}

Dietary S. platensis supplementation did not have significant effect on egg production or HSP70 gene expression in the heart or liver of Japanese quails. However, adding S. platensis at the level of $0.5 \%$ caused the lowest intestinal E. coli population, blood MDA level, heterophil, $\mathrm{H} / \mathrm{L}$ ratio, in quails under heat stress $(p<0.05)$. Thus, it seems that $S$. Platensis had the potential to decrease heat stress in laying quails and may be considered as a probiotic alternative in heat stress condition, however, further research is needed to clear its effects in detail.

\section{DISCLOSURE STATEMENT}

The authors declare that there is no potential conflict of interest.

\section{FUNDING}

The authors would like to thank for the support from the vice president of research at the University of Tehran, Iran (Project code: 79/35923).

\section{REFERENCES}

Abouelezz, FMK. Evaluation of Spirulina algae (Spirulina platensis) as a feed supplement for Japanese quail: Nutritional effects on growth performance, egg production, egg quality, blood metabolites, sperm-egg penetration and fertility. Egyptian Poultry Science Journal 2017;37(3):709-721.

AOAC-Association of Official Analytical Chemists. Official methods of analysis. $18^{\text {th }}$ ed. Washington; 2007.

Assis LMD, Machado AR, Motta ADSD, Costa JAV, Soares LADS Development and characterization of nanovesicles containing phenolic compounds of microalgae Spirulina strain LEB-18 and Chlorella pyrenoidosa. Advances in Materials Physics and Chemistry 2014;4:612

Attia YA, Hassan RA, Tag El Din AE, Aboushehema BM. Effect of ascorbic acid or increasing metabolizable energy level with or without supplementation of some essential amino acids on productive and physiological traits of slow growing chicks exposed to chronic heat stress. Journal of Animal Physiology and Animal Nutrition 2011;95:744755.

Balasundram N, Sundram K, Samman S. Phenolic compounds in plants and agro-industrial by-products: antioxidant activity, occurrence, and potential uses. Food Chemistry 2006;99:191-203.

Chu WL. Potential applications of antioxidant compounds derived from algae. Current Topics in Nutraceuticals Research 2011;9(3), 83.

Craig EA, Gross CA. Is HSP70 the cellular thermometer? Trends in Biochemical Sciences 1991;16:135-140.

Demule MCZ, Decaire GZ, Decano MS. Bioactive substances from Spirulina platensis (Cyanobacteria). International Journal of Experimental Botany 1996;58:93-96

Dogan SC, Baylan M, Erdogan Z, Akpinar GC, Kucukgul A, Duzguner V. Performance, egg quality and serum parameters of Japanese quails fed diet supplemented with Spirulina platensis. Fresenius Environmental Bulletin 2016;25(25):5857-62.

Farag MR, Alagawany M, Abd El-Hack ME, Dhama K. Nutritional and healthical aspects of Spirulina (Arthrospira) for poultry, animals and human. International Journal of Pharmacology 2016;12:36-51.

Fazilati M, Latifi AM, Salavati H, Choopani A. Antioxidant properties of Spirulina. Journal of Applied Biotechnology Reports 2016;3(1):345351.

Gaviol HCT, Gasparino E, Prioli AJ, Soares MAM. Genetic evaluation of the HSP70 protein in the Japanese quail (Coturnix japonica). Genetics and Molecular Research 2008;7(1):133-139

Georgieva NV, Koinarsk V, Gadjeva V. Antioxidant status during the course of Eimeriatenella infection in broiler chickens. Veterinary Journal 2006;172:488-92.

Hafting JT, Critchley AT, Cornish ML, Hubley SA, Archibald AF. On-land cultivation of functional seaweed products for human usage. Journal of Applied Phycology 2012;24(3):385-392.

Hajati H, Hassanabadi A, Golian A, Nassiri-Moghaddam H, Nassiri MR. The effect of grape seed extract and vitamin $C$ feed supplementation on some blood parameters and HSP70 gene expression of broiler chickens suffering from chronic heat stress. Italian Journal of Animal Science $2015 ; 14(3): 3273$

Hajiaghapour, M, Rezaeipour V. Comparison of two herbal essential oils, probiotic, and mannan-oligosaccharides on egg production, hatchability, serum metabolites, intestinal morphology, and microbiota activity of quail breeders. Livestock Science 2018;210:93-98.

Hu CH, Gu LY, Luan Z, Song J, Zhu K. Effects of montmorillonite-zinc oxide hybrid on performance, diarrhea, intestinal permeability and morphology of weanling pigs. Animal Feed Science and Technology 2012;177:108-115.

Klein B, Buchholz R. Microalgae as sources of food ingredients and nutraceuticals. In: Giavasis I, Harvey L, Archer D. Microbial production of food ingredients, enzymes and nutraceuticals. Oxford: WP; 2013. p.559-570.

Kulshreshtha A, Jarouliya U, Bhadauriya P, Prasad GBKS, Bisen PS. Spirulina in health care management. Current Pharmaceutical Biotechnology 2008;9(5):400-405 
Lampe MF Ballweber LM, Isaacs CE, Patton DL, Stamm WE. Killing of Chlamydia trachomatis by novel antimicrobial lipids adapted from compounds in human breast milk. Antimicrobial Agents and Chemotherapy 1998;42(5):1239-1244.

Lara LJ, Rostagno MH. Impact of heat stress on poultry production. Animals 2013;3:356-369

Li YZ, Li J, Zhang NB, Chen CX, Cui YQ. Diversity analysis of the intestinal microbial flora of laying hens underheat stress. Acta Ecologica Sinica 2015;35(5):1-13.

Livak, KJ, Schmittgen TD. Analysis of relative gene expression data using real-time quantitative PCR and the $2-\triangle \Delta C T$ method. Methods 2001;25(4):402-408

Mahmoud KZ, Edens FW, Eisen EJ, Havenstein GB. Ascorbic acid decreases heat shock protein 70 and plasma corticosterone response in broilers (Gallus gallusdomesticus) subjected to cyclic heat stress. Comparative Biochemistry and Physiology 2004;137:35-42.

Mala R, Sarojini M, Saravanababu S, Umadevi G. Screening for antimicrobial activity of crude extracts of Spirulina platensis. Journal of Cell and Tissue Research 2009;9:1951-1955.

Manafi M, Khalaji S, Hedayati M. Assessment of a probiotic containing Bacillus subtilis on the performance and gut health of laying Japanese quails (Coturnix coturnix Japonica). Brazilian Journal of Poultry Science 2016;18(4):599-606

Manafi M. Comparison study of a natural non-antibiotic growth promoter and a commercial probiotic on growth performance, immune response and biochemical parameters of broiler chick. Journal of Poultry Science 2015;52:274-281.

Mariey YA, Samak HR, Ibrahem MA. Effect of using Spirulinaplatensis algae as a feed additive for poultry diets:1- productive and reproductive performances of local laying hens. Egyptian Poultry Science Journal 2012;32:201-15

Mihara M, Uchiyama M. Determination of malonaldehyde precursors in tissues by thiobarbituric acid test. Analytical Biochemistry 1978;86:271278.

Miranda MS, Cintra RG, Barros SBM, Mancini-Filho J. Antioxidant activity of the microalga Spirulina maxima. Brazilian Journal of Medical and Biological Research 1998;31(8):1075-1079.

Mishra PM, Sree A. Antibacterial activity and GCMS analysis of the extract of leaves of Finlaysoniaobovata (a mangrove plant). Asian Journal of Plant Sciences 2007;6(1):168-172.

Misra DS, Maiti R, Ghosh D. Protection of swimming-induced oxidative stress in some vital organs by the treatment of composite extract of Withania somnifera, Ocimum sanctum and Zingiber officinalis in male rat. African Journal of Traditional, Complementary and Alternative Medicines 2009;6(4):534-543.

North MO, Bell DD. Commercial chicken production manual. $4^{\text {th }}$ ed. New York: Van Nostrand Reinhold; 1990.

NRC- National Research Council. Nutrient requirements of poultry. $9^{\text {th }}$ ed. Washington: National Academy Press; 1994.

Ojha R, Prasad R, Manzoor N, Ahmad Khan L. Vitamin C modulates oxidative stress related enzyme activities in Candida albicans. Turkiah Journal of Biochemistry 2010;35:35-40.

Paglia DE, Valentine WN. Studies on the quantitative and qualitative characterization of erythrocyte glutathione peroxidase. Journal of Laboratory and Clinical Medicine 1967;70:158-169.
Park JH, Lee SI, Kim IH. Effect of dietary Spirulina (Arthrospira) platensis on the growth performance, antioxidant enzyme activity, nutrient digestibility, cecal microflora, excreta noxious gas emission, and breast meat quality of broiler chickens. Poultry Science 2018;97:2451-2459.

Pradhan J, Das S, Das BK. Antibacterial activity of freshwater microalgae:A review. African Journal of Pharmacy and Pharmacology. 2014;8 (32):809-18.

Qureshi MA, Garlich JD, Kidd MT. Dietary Spirulina platensisenhances humoral and cell-mediated immune functions in chickens. Immunopharmacology and Immunotoxicology 1996;18(3):465-476.

Rezaeipour V, Valizadeh A, Abdullahpour R, Sadeghi AR. Effects of dietary threonine and a multi strains probiotic (Primalac) supplementation on growth performance, blood metabolites and carcass characteristics in Japanese quails. Poultry Science Journal.2015;3(2):135-141.

Rodrigo R, Miranda A, Vergara L. Modulation of endogenous antioxidant system by wine polyphenols in human disease. Clinica Chimica Acta 2011;412:410-424

Romay C, Gonzalez R. Phycocyanin is an antioxidant protector of human erythrocytes against lysis by peroxyl radicals. Journal of Pharmacy and Pharmacology 2000;52(4):367-368

Sahin N, Tuzcu M, Orhan C, Onderci M, Eroksuz Y, Sahin K. The effects of vitamin $C$ and $E$ supplementation on heat shock protein 70 response of ovary and brain in heat-stressed quail. British Poultry Science 2009;50:259-265

SAS. User's guide: statistics. Version 9.1. Cary; 2003.

Shanmugapriya B, Babu SS, Hariharan T, Sivaneswaran S. Anusha MB. Dietary administration of Spirulinaplatensis as probiotics on health and histopathology in broiler chicks. International Journal of Recent Scientific Research 2015;6:2650-2653

Sohail MU, Hume ME, Byrd JA, Nisbet DJ, ljaz A, Sohail A, et al., Effect of supplementation of prebiotic mannan-oligosaccharides and probiotic mixture on growth performance of broilers subjected to chronic heat stress. Poultry Science 2012;91(9):2235-2240.

Sousa MS, Tinoco I de FF, Barreto SL de T, Amaral AG do, Pires LC, Ferreira AS. Determinação de limites superiores da zona de conforto térmico para codornas de corte aclimatizadas no Brasil de 22 a 35 dias de idade. Revista Brasileira de Saúde e Produção Animal 2014;15:350-360.

Sugiharto S, Yudiarti T, Isroli I, Widiastuti E, Kusumanti, E. Dietary supplementation of probiotics in poultry exposed to heat stress-a review. Annals of Animal Sciences 2017;17(3):591-604.

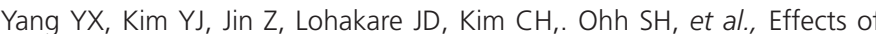
dietary supplementation of astaxanthin on production performance, egg quality in layers and meat quality in finishing pigs. Asian Australian Journal of Animal Science 2006;19(7):1019.

Yu H, Jia S, Dai Y. Growth characteristics of the cyanobacterium Nostoc flagelliforme in photoautotrophic, mixotrophic and heterotrophic cultivation. Journal of Applied Phycology. 2009;21(1):127.

Zhang WW, Kong LN, Zhang XQ, Luo QB. Alteration of HSF3 and HSP70 mRNA expression in the tissues of two chicken breeds during acute heat stress. Genetics and Molecular Research 2014;13(4):9787-9794. 